\title{
An Investigation of the Learning styles and Study Habits of Chemistry Undergraduates in Barbados and their Effect as Predictors of Academic Achievement in Chemical Group Theory
}

\author{
Leah D Garner-O'Neale, PhD \\ Shannie Harrison \\ Department of Biological \& Chemical Sciences \\ Faculty of Science \& Technology \\ The University of the West Indies \\ Cave Hill Campus, Barbados \\ Email: leah.garner-oneale@cavehill.uwi.edu
}

\section{Doi:10.5901/jesr.2013.v3n2p107}

\begin{abstract}
:
This study was performed to investigate the learning styles, study habits and academic achievement of Chemistry students enrolled at the University of the West Indies (the UWI), Cave Hill Campus. The questionnaire used to assess these variables consisted of the Paragon Learning Style Inventory which measures the four learning style dimensions extrovert/introvert, sensate/intuitive, feeling/thinking and judging/perceiving along with the Study Habits Inventory which measures the study habits displayed by the students. There were 59 students who participated in the study. The reliability of inventories was determined using the Cronbach coefficient alpha. The data collected was analyzed by the t-test, ANOVA and linear regression at a confidence level of 0.05 . It was concluded that among the students the introvert, sensate, thinking and judging learning styles were most prevalent. There was no statistical difference in the study habits of the students based on level or the learning styles based on level, and study habits or academic achievement based on study habits and learning styles. The contribution of the learning styles and study habits as predictors of a chemistry student's academic achievement in group theory was not significant however, extrovert/introvert learning style dimension is the highest contributor.
\end{abstract}

Key words: Learning styles, academic achievement, study habits, gender, science

\section{Background}

\subsection{Learning Styles}

We as human beings recognize that we are not the same through our observations and interactions with each other. We look, speak and act differently, even our preferences and choices in life are completely different. It is therefore not inconceivable to think that we can learn differently as well (Schmid, Yeung, \& Read, 2009). Each individual has a special way of grasping a particular concept or situation (Bailey \& Garratt, 2002). That is, he/she prefers to learn via different styles. Over the years there have been several different ways of defining a learning style. Smith \& Dalton (2005) defines a learning style as a unique and habitual behaviour of acquiring knowledge and skills through everyday study or experience. Felder \& Silverman (1988) describes it as the way in which persons receive and process information. Kolb (1984) has his own opinion as to what a learning style is and defines it as the process of creating knowledge through the transformation of experience. The general theme of these definitions suggests that learning style encompasses the acquiring, processing and recalling information by an individual through particular experiences. 
Aging and maturity may accompany a change in the learning preference of an individual as there is development in the person's perception and ability to understand a particular concept/situation. It is not something that might necessarily occur overnight but as the years progress a gradual change may occur leading to one main preference. As mentioned before this maturity could also lead to the development of some or all of the learning styles and consequently, an adaptable person. Knowing one's best learning style helps to optimize the amount of knowledge that can be possibly acquired within a given time period (Kazu, 2009; Yeung, Read, \& Schmid, 2006). This could also possibly lead to the improvement of the students' academic performance during the semester (Yeung, et al., 2006). In most cases, an individual may have a more dominant or preferred style of learning and mainly uses that style to process a concept/situation. However, persons maybe adaptable and change to a different learning style based on the particular situation that is encountered. This observation may come as a result of persons having a mixture of various learning styles (Huang \& Busby, 2007).

\subsection{Learning Styles and Academic Achievement}

Academic performance or achievement represents the amount of knowledge and skills developed by a student in various courses. The level of academic achievement or success is measured by tests, assignments and final examination results and is dependent on the standards put in place by the educational institution (Nuthana \& Yenagi, 2009). It has been suggested that those students with multiple learning styles tend to do better academically than those with just one dominant style (Abidin, Rezaee, Abdullah, \& Singh, 2011).

\subsection{Learning Style Inventories}

For years there have been several opinions and theories behind the way persons should be grouped according to how they learn. Persons such as David Kolb, Isabel Briggs Myers, Anthony Grasha and Sheryl HruskaRiechmann among many others have delved into the subject to create their own learning style models and help persons determine their own learning style preference (Felder \& Silverman, 1988; Kolb, 1981; Montgomery \& Groat, 1998).

The Index of Learning Styles instrument was developed by Felder and Barbara A. Soloman and is based off of the Silverman-Felder learning style model was created by Richard Felder and Linda Silverman. The inventory itself contains 44 questions which seek to assess the preferences of students based on the four dimensions that constitute the inventory which are sensing/intuiting, visual/verbal, active/reflective and sequential/global (Felder \& Silverman, 1988). The sensing/intuiting dimension was based on both Carl Jung's theories and the active/reflective was based on Kolb's theories. This model has been applied in the classification of engineering students (Felder \& Silverman, 1988).

The Kolb Learning Style Inventory (KLSI) developed by David Kolb is associated with experiential learning process. It is characterized by four different stages and these are Concrete Experience, Abstract Conceptualization, Reflective Observation and Active Experimentation (Kolb, 1981). He formulated these four stages into two major dimensions: active/reflective and abstract/concrete. The inventory evaluates individuals based on four learning style preferences: Diverging, Converging, Assimilating, and the Accommodating (Kolb, 1981). The KLSI has been used successfully among science students (Jones, Reichard, \& Mokhtari, 2003) and students studying architecture (Tucker, 2007).

Myer-Briggs Type Indicator (MBTI) was developed in 1962 by Isabel Briggs Myer and Katharine C. Briggs. The MBTI is also based on Carl Jung's psychological theories (Varughese, 2007; O'Brien, Bernold, \& Akroyd, 1998). The model assesses the personality types of individuals and like other models, consists of four dimensions. It measures the learning style preferences: extrovert/introvert, sensate/intuitive, feeling/thinking and judging/perceiving and has been used to classify students doing science (O'Brien, et al., 1998). Two dimensions associated with the KLSI correlate to two in the MBTI. It was noticed that the Active/Reflective dimension in the KLSI is essentially the Extrovert/Introvert dimension in MBTI and Concrete/Experience is Feeling/Thinking (Kolb, Boyatzis, \& Mainemelis, 2001). The model like the KLSI has been used in the evaluation of science students but in this case engineering (O'Brien, et al., 1998).

Anthony Grasha and Sheryl Hruska-Riechmann also developed a model, Grasha-Reichmann Learning Style, but unlike the other models which tend to derive from more personality or psychological traits, it is based on 
students' reactions to classroom activities and settings (Montgomery \& Groat, 1998). The model consists of six learning styles but divided into three dimensions. It evaluates students on competitive/collaborative, avoidant/participant, dependent/independent learning styles (Montgomery \& Groat, 1998). This instrument has been used in the assessment of both science and social science students (Hamidah, Sarina, \& Jusoff, 2009).

The Paragon Learning Style Inventory (PLSI) is a modified version of the Myer-Briggs Type Indicator (MBTI). The MBTI model mainly targeted persons 14 years or older and Dr. John Shindler felt that the complex structure of the questions and the language used was not entirely appropriate for younger students (Varughese, 2007). This led to the modification of the MBTI and the birth of PSLI by Shindler and Dr. Harrison-Yang. Thus, the learning styles associated with PLSI like the MBTI are also based on personality. Moreover, the PSLI has also been used in the evaluation of students at the tertiary level. In fact, it has been specifically used in the evaluation of first year chemistry students (Tasker, Miller, Kemmett, \& Bedgood Jr, 2003; (Yeung, Read, \& Schmid, 2005) and proven to be successful. Its previous use in other studies along with its availability and the range of its assessment (8 years and older) led to the decision of making PSLI the choice of study.

\subsection{Paragon Learning Style Inventory}

Essentially, the Paragon Learning Style Inventory is a survey consisting of 48 questions used in assessing the different learning styles and preferences among individuals. There are approximately sixteen learning styles within the model which originate from four different pairs of dimensions. Persons can be categorized as introvert/extrovert, sensate/intuitive, thinking/feeling and judging/perceiving (Yeung, et al., 2005). The introvert/extrovert (E/I) dimension deals with the interaction between people and concepts. The extrovert mainly focuses on the outside world and prefers to try things out for himself. On the other hand, introverts deal with the inner world and reflect on thoughts and ideas. The introvert is quiet and prefers to be alone. This type of person would prefer to watch a demonstration of a specific task to be done before attempting it (Larkin-Hein $\&$ Budny, 2000).

The sensate/intuitive $(\mathrm{S} / \mathrm{N})$ dimension pertains to how information is acquired or absorbed. Sensors use their senses (e.g sight or hearing) to relay and interpret information. They rely on past experiences and known facts to understand a concept. Persons who depend more on their intuitive thinking are imaginative and abstract. They have a tendency to make speculations to determine whether something is possible and try to envision ideas (O'Brien, et al., 1998; Varughese, 2007).

The thinking/feeling (T/F) dimension is more concerned with the decision making process of the individual. Feelers are interested in people and values but not ideas. This person makes decisions based on the people and their actions. Thinkers on the other hand, make logical and rational decisions and loves ideas and concepts (Varughese, 2007).

The last dimension, judging/perceiving $(\mathrm{J} / \mathrm{P})$ is associated with how a person prefers to live their own individual lives. Persons who are judgers primarily prefer to be well organized and orderly. They are decisive people who may also feel accomplished when their work has been fully completed. Unlike the judgers, perceivers are more spontaneous and flexible when it comes to their lives and with everyday tasks. They can be very indecisive which can be clearly seen as the opposite of the judgers (Larkin-Hein \& Budny, 2000; Yeung, et al., 2005).

A combination of the learning style preferences gives rise to sixteen possible learning styles ISTJ, ISFJ, INFJ, INTJ, ISTP, ISFP, INFP, INTP, ESTP, ESFP, ENFP, ENTP, ESTJ, ESFJ, ENFJ and ENTJ (Shabani, 2012) and these are illustrated in Table 1. 
Table 1: The Sixteen Learning Styles Associated with the Paragon Learning Style

\begin{tabular}{|c|c|c|c|}
\hline $\begin{array}{l}\text { ISTJ } \\
\text { Introvert Sensate } \\
\text { Thinking Judging }\end{array}$ & $\begin{array}{l}\text { ISFJ } \\
\text { Introvert Sensate } \\
\text { Feeling Judging }\end{array}$ & $\begin{array}{l}\text { INFJ } \\
\text { Introvert Intuitive } \\
\text { Feeling Judging }\end{array}$ & $\begin{array}{l}\text { INTJ } \\
\text { Introvert Intuitive } \\
\text { Thinking Judging }\end{array}$ \\
\hline $\begin{array}{l}\text { ISTP } \\
\text { Introvert Sensate } \\
\text { Thinking Perceiving }\end{array}$ & $\begin{array}{l}\text { ISFP } \\
\text { Introvert Sensate } \\
\text { Feeling Perceiving }\end{array}$ & $\begin{array}{l}\text { INFP } \\
\text { Introvert Intuitive } \\
\text { Feeling Perceiving }\end{array}$ & $\begin{array}{l}\text { INTP } \\
\text { Introvert Intuitive } \\
\text { Thinking Perceiving }\end{array}$ \\
\hline $\begin{array}{l}\text { ESTP } \\
\text { Extrovert Sensate } \\
\text { Thinking Perceiving }\end{array}$ & $\begin{array}{l}\text { ESFP } \\
\text { Extrovert Sensate } \\
\text { Feeling Perceiving }\end{array}$ & $\begin{array}{l}\text { ENFP } \\
\text { Extrovert Intuitive } \\
\text { Feeling Perceiving }\end{array}$ & $\begin{array}{l}\text { ENTP } \\
\text { Extrovert Intuitive } \\
\text { Thinking Perceiving }\end{array}$ \\
\hline $\begin{array}{l}\text { ESTJ } \\
\text { Extrovert Sensate } \\
\text { Thinking Judging }\end{array}$ & $\begin{array}{l}\text { ESFJ } \\
\text { Extrovert Sensate } \\
\text { Feeling Judging }\end{array}$ & $\begin{array}{l}\text { ENFJ } \\
\text { Extrovert Intuitive } \\
\text { Feeling Judging }\end{array}$ & $\begin{array}{l}\text { ENTJ } \\
\text { Extrovert Intuitive } \\
\text { Thinking Judging }\end{array}$ \\
\hline
\end{tabular}

PLSI being self-scored can be quite helpful to students in predicting the career choices of the students given that each learning style is associated with particular careers. For example the student who had a preference for the extrovert, sensing, feeling and thinking (ESFJ) learning style it has been suggested that a career in education or healthcare would be more suited toward the individual (Varughese, 2007) since persons with this type of learning style are friendly, organized and tend to be gain satisfaction from helping others (Larkin-Hein \& Budny, 2000; Varughese, 2007). Another example is introvert, intuitive, thinking and judging (INTJ) which is associated with a career in science (Varughese, 2007) given that persons with the INTJ learning styles usually their logical thinking and creativity to create plans complete tasks (Larkin-Hein \& Budny, 2000; Varughese, 2007).

\subsection{Learning Styles and Study Habits}

Knowing one's learning style(s) is imperative but being able to master one's study habits and skills could tremendously reduce the issues of underachievement that is still on the rise among students (Gettinger \& Seibert, 2002; Rana \& Kausar, 2011) Study habits on the other hand, refer to the tendency of a student to use his/her uninterrupted attention to acquire knowledge via systematic routines (Credé \& Kuncel, 2008; Khurshid, Tanveer, \& Qasmi, 2012). Study skills refer to effective study strategies and techniques in time management as well as other resources to attain academic success (Credé \& Kuncel, 2008). In essence study habits could be viewed as the continuous practice or repetition of study skills over time.

In addition, once learning styles are identified, students may discover that their study habits are not connected or matched to their learning styles. For instance extroverts are better at socializing and communicating with other persons unlike the introverts. Therefore, the extroverts may work with study groups rather than alone. This way they can study according to their learning style and possibly improve academically. Hoeffner (2010) sought to determine whether there was an improvement in grades after the adjustment of their study habits once their learning styles were identified. This study was inconclusive since not all of the students modified their study habits. However, those who did modify their study habits in relation with their learning styles agreed that the change was quite beneficial (Hoeffner, 2010).

\subsection{Study Habits Inventories}

Similar to the development of learning style inventories, a few researchers also formulated their own study habit inventories (Khurshid, et al., 2012; Richards, Richards, \& Sheridan, 1999; Estes \& Richards, 1985). Herbert Richards and Thomas Estes developed a study habit inventory derived from C. Gilbert Wrenn's initial work (Richards, et al., 1999; Blumner \& Richards, 1997). The inventory was developed for classifying both high school and college students based on three factors which included distractibility, inquisitiveness and compulsiveness (Richards, et al., 1999). The survey has been used in assessing college engineering students (Blumner \& Richards, 1997). 
Another study habit inventory was developed by Dennis Congos and has been used to investigate academic performance among university level students. The inventory consists of 49 questions based on test, preparation, concentration, time management, text book, note taking and memory (Khurshid, et al., 2012).

\subsection{Adapted Study Habits Inventory}

In this paper, study habits of students will be examined using an adapted version of the Study Habits Inventory from C. Gilbert Wrenn. The original inventory was developed in 1933 and the revised in 1941. The inventory focused on note taking, concentration, reading and time management skills (Wrenn, Larsen, \& Effectively, 1974). An online modified version of the inventory was available and this led to the choice of studying this particular inventory. The adapted inventory used in the study looks at the overall level of study habits among the students based on poor or good study habits. It is thought that there is a relationship between study habits and academic performance among students (Aluja-Fabregat \& Blanch, 2004; Bashir \& Mattoo, 2012). Students with poor study habits either lack effective or organized study routines while those with good study skills have more organized routines where they focus more effectively on the work at hand (Gettinger \& Seibert, 2002).

\subsection{Study Habits and Academic Achievement}

Gettinger \& Seibert (2002) stated that students who demonstrate poor study habits, are most likely the ones to have low academic achievement. Having good study habits could reduce the failure rate within educational institutions since studying tends to increase a student's academic ability (Gettinger \& Seibert, 2002). Therefore, while some students may not find studying to be interesting, it is quite effective for achieving good overall grades (Rana \& Kausar, 2011).

For many students, being the best, doing the best and striving for overall excellence is the ultimate goal at whatever educational institution they may be enrolled in. Consequently, it is important to have learning styles, study skills and habits as they not only pertain to short term situations but can be extremely advantageous further on in life as fresh challenges are likely to be faced such as obtaining new jobs, the task of running a household and balancing finances are some of the many challenges that could be encountered as a person ages.

\subsection{Assessment and Academic Achievement}

The type of assessment chosen for the study was based on Chemical Group Theory since it encompasses various forms of learning abilities seeing as a student will have to use logical thinking for the mathematical portion of the subject, imagination to visualize the molecule in space (Harle \& Towns, 2010), visibly observing models or diagrams and in some cases hands on experience which would entail the building of models of the molecules (Harle \& Towns, 2010; Meyer \& Sargent, 2007).

The structure or types of assessments used by the lecturers may not cater to the diverse learning styles among the students. In the case of extroverts assessments may come in the form of debates or group projects. These are more in alignment with their learning styles as opposed to individual tests and assignments. This observation may suggest that there may be link between assessment and academic achievement. Students should perform better when their learning styles are accommodated in their individual assessments.

\section{Purpose of the Study}

This study investigated the self reported learning styles and study habits of first and third year chemistry students at the University of the West Indies, Cave Hill Campus. The research sought to determine whether there were any significant differences in these learning styles and study habits based on their sex (male/female), and level of study. It also sought to determine to what extent their study habits and learning style individually or collectively act as predictors for their academic achievement in chemistry. The information gathered from this study will serve to inform the lecturers assessment practices regarding the diversity of their students. 


\section{Research Questions:}

To specifically attain insight on the topics, the following research questions will be answered.

1. What are the prevailing learning style preferences among undergraduate chemistry students in the Department of Biological and Chemical Sciences?

2. What percentage of undergraduate chemistry students displays good study habits?

3. Is there any significant difference in the level of study habits of undergraduate chemistry students in the Department of Biological and Chemical Sciences based on level of study

4. Is there any significant difference in the learning style preferences of undergraduate chemistry students in the Department of Biological and Chemical Sciences based on

i. Level of study

ii. Study Habits

5. Is there any significant difference in the academic achievement of undergraduate chemistry students in group theory based on

i. Study Habits

ii. Learning Styles

6. To what extent do study habits and learning styles combined predict the level of academic achievement of the undergraduate chemistry students in group theory?

7. What is the relative contribution of each factor of study habits and learning styles on the level of academic achievement of the undergraduate chemistry students in group theory?

\section{Methodology}

\subsection{Research Design}

A survey or descriptive research design was used in this study. It was used because it allowed the researchers to collect data regarding the opinion of the participants on a particular topic (Leacock, Warrican \& Rose, 2009).

\subsection{Instrumentation}

A questionnaire named the Student Learning Preference Questionnaire was used in the study. The instrument consisted of three sections.

Section A: Demographic information and Academic Experience

Section B: The Paragon Learning Style Inventory

Section C: The Study Habits Inventory

The demographic information and academic experience section gathered data such as sex (male/female), level and course of study. The Paragon Learning Style Inventory (Shindler and Yang, 2004) consisted of 48 questions with 12 questions relating to each of 4 dimensions. For each question either "a" or " $b$ " was best represented the participant most frequently. The Study Habits Inventory was adapted from Wrenn et al (1974). It consisted of 11 questions and used a 4-point likert scale.

\subsection{Pilot Study}

The PLSI was previously used in other studies and has been proven to be stable and have high validity and reliability (Varughese, 2007; Yeung, et al., 2005; Yeung, et al., 2006) but both the PLSI and the Study Habits Inventory were developed for use in a different cultural setting than the Caribbean so the pilot study was performed to identify, remove/modify any ambiguous questions that may be encountered as well as to investigate the degree of internal consistency of the questions pertaining to the inventories used. All of the second year inorganic students participated in the pilot. These were chosen because they have already passed the $1^{\text {st }}$ year group theory and are the potential students for the final year group theory. It was thought that these students therefore represented characteristics of both groups. The data from the collected questionnaires was entered and processed using a computer programme, Predictive Analytics Software (PASW) Statistics 19 
formerly known as Statistical Programme for Social Sciences (SPSS), to determine the reliability of the questions of both inventories within the pilot study. The Cronbach alpha is a measure of internal consistency and can be used to determine the reliability of the scales (Santos, 1999; Tavakol \& Dennick, 2011). If removing a question increased the alpha value, then it was removed. The final adapted PLSI was a 42 item questionnaire with alpha values of 0.64 in the E/I category; 0.46 in the S/N category; 0.68 in the J/P category and 0.44 in the T/F category. The Study Habit Inventory had an alpha value of 0.73 .

\subsection{Actual Study}

\subsubsection{Sample}

A total of $591^{\text {st }}$ and $3^{\text {rd }}$ year students at the Cave Hill campus of the University of the West Indies voluntarily participated in the study. Of the 59 students there were 10 males and 49 females; 37 were in $1^{\text {st }}$ year and 22 were in $3^{\text {rd }}$ year; 37 of the participants declared chemistry as their major/minor and 22 of the participants were taking chemistry for extra credits.

\subsubsection{Data Analysis \& Scoring Scheme}

Good study habits refer to good note taking, test anxiety, reading comprehension, concentration and time management skills. In this case one number was picked from a range of 1-4 where ' 1 ' was 'always true' and ' 4 ' was 'rarely true'. With each question of the 11 questions having a maximum score 4 it was deduced that the highest overall score that any one student can attain is 44 (good study habits) and the lowest is 11 (poor study habits). Thus, an overall score of 33 and above was deemed as having good study habits while a score below 33 was deemed as bad study habits.

PASW Statistics 19 and was used in the analysis of the collected data. The frequencies and percentages for the demographic data were analyzed using PASW. The frequencies and percentages for the various learning styles were analyzed for research question 1 which dealt with the prevailing learning styles and question 2 which dealt with the percentage of students that display good study habits. Question 3 which dealt with the significant difference between study habits based on level, were analyzed via the t-test of Independent Samples and ANOVA respectively. To answer questions 4 (i) and (ii) (is there any significant difference in the learning style preferences of undergraduate chemistry students based on level of study and study habits) the t-test for Independent Samples was employed. To determine question 5 (if there was any significant difference in the academic achievement of undergraduate chemistry students in group theory based on study habits and learning styles) t-tests were performed. Linear regression was used to determine the extent that study habits and learning styles combined predict academic achievement as well as their relative contribution on the level of academic achievement. A confidence level of 0.05 was utilized for the duration of the study.

\section{Results \& Discussion}

\subsection{Distribution of gender, level of study and major}

There were more females $(83,1 \%)$ than males $(16,9 \%)$ who participated in the study. This was expected since there are more females taking chemistry but the percent difference was unexpectedly high. This observation does not support the concept that more males prefer science than females (Linn \& Hyde, 1989). However, it does align with the fact that the university has more females than males since there are approximately 8,500 students enrolled at the university with $70 \%$ being female and $30 \%$ being male ("International Office: International Students: FAQs,"). Of the participants $62,7 \%$ were declared as Chemistry majors or minors while $37,3 \%$ were just taking Chemistry courses. The majority of the students taking chemistry courses in the first year are biochemistry majors who are required to complete the $1^{\text {st }}$ year chemistry course as a prerequisite for their majors. 


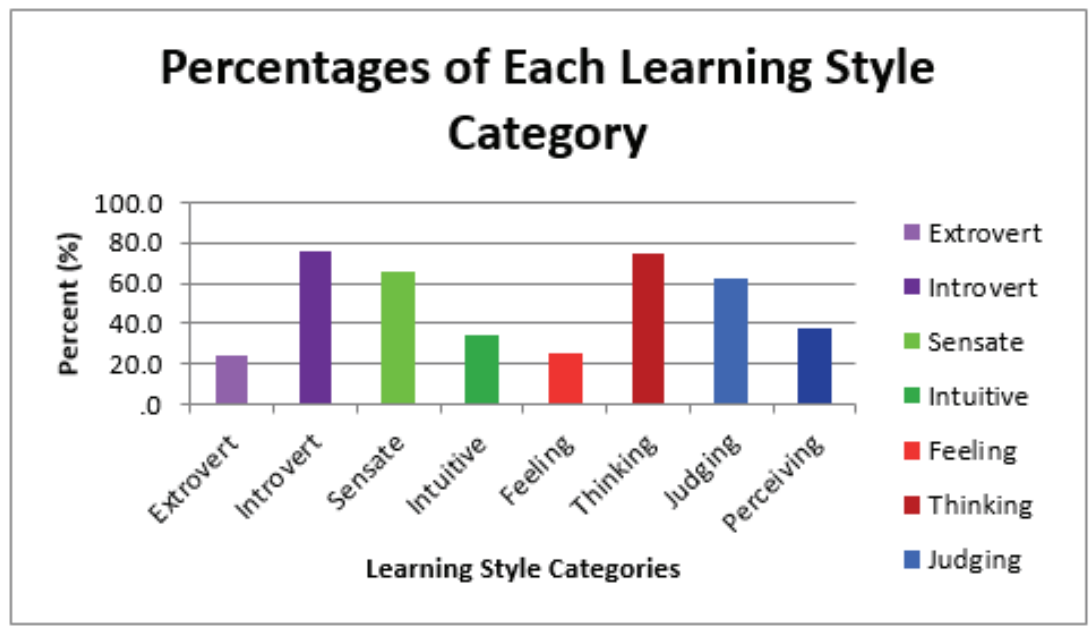

Figure 1: The percentages of each learning style category

Figure 1 exemplifies the learning style preferences that characterize the undergraduate chemistry students. There was a higher percentage of introverts (76.35\%) compared to extroverts $(23,7 \%)$. Chemistry involves more individual work than group work which may be preferred more by the introverts given that they prefer working alone (Varughese, 2007) and may use their time alone to reflect on their work more thoroughly (Hauptman \& Cohen, 2011; Varughese, 2007). Another study also suggested that due to this preference, introverts may gravitate toward Chemistry. In the case of the sensate/intuitive dimension the students showed a higher preference for the sensate learning style $(66,1 \%)$ than intuitive $(33,9 \%)$. This was quite unexpected given that chemistry involves more abstract concepts and theories (Felder, Felder, \& Dietz, 2002) which may be more suited to the intuitive students. Sensors on the other hand, prefer to use their senses and past experiences (O'Brien, et al., 1998; Varughese, 2007) and may have difficulty with grasping concepts that are not practical (Hauptman \& Cohen, 2011). It was noticed that the thinkers $(74,6 \%)$ outweighed the feelers $(25,4 \%)$. This was expected since chemistry requires more logical, analytical and rational evaluation of the information presented (O'Brien, et al., 1998; Varughese, 2007). The last dimension was judging/perceiving and as expected a higher percentage of the students were judgers $(63,7 \%)$ compared to the perceivers (37,3\%). Judgers tend to prefer more structured and organized instruction which is associated with chemistry and maybe the reason for such an observation (Felder, et al., 2002).Thus, the most prevailing learning style preferences among the $1^{\text {st }}$ and $3^{\text {rd }}$ year chemistry students at the UWI were introvert $(76.35 \%)$, sensate $(66,1 \%)$, thinking $(74,6 \%)$ and judging $(62,7 \%)$ and this is in agreement with a study carried out by Yeung, et al., (2005) which reported that among undergraduate chemistry students introverts, sensate, thinking and judging were also prevalent.

\subsection{Study Habits (SH)}

The investigation of study habits among the students was carried out to determine whether they displayed good or poor study habits (Research question 2) and is illustrated in Table 2 and Figure 2.

Table 2: Mean and Standard Deviation of Study Habits

\begin{tabular}{|l|l|l|l|}
\hline & N & Mean & Standard Deviation \\
\hline Study Habits & 59 & 1.41 & 0.495 \\
\hline
\end{tabular}




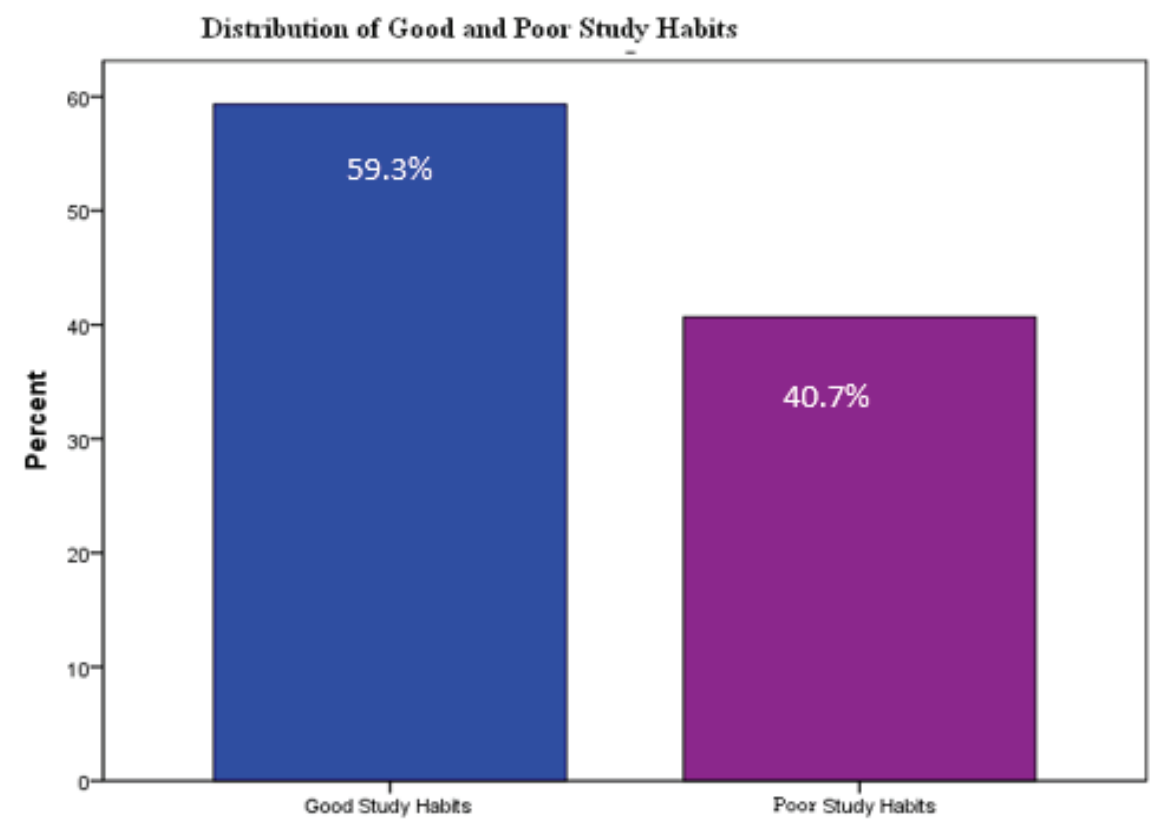

Figure 2: Percentage of students with good and poor study habits

A score $\geq 33$ represents good study habits and $<33$ represent poor study habits. Table 2 provides the mean and standard deviation that were calculated for the combined total of study habit scores. In this case, a value of 1 would represent good study habits while a value of 2 would represent poor study habits. Therefore, a mean of 1.41 which is closer in value to one indicates that more students displayed good study habits. Figure 2 further demonstrates this by showing that a proportion $(59,3 \%)$ of students within the study displayed better study habits than the other $40,7 \%$ of the students.

The study further investigates the significant difference in the level of study habits based on the level of study the students are at (Research question 3). Table 3 and 4 illustrate the relationship of the level of study habits of the participants based on their level of study.

Table 3: Comparison of the Study habits based on the Level of Study

\begin{tabular}{|l|c|c|c|c|c|}
\hline & Level & N & Mean & Std. Deviation & Std. Error Mean \\
\hline \multirow{3}{*}{ SH combined } & First Year & 37 & 32.54 & 4.266 & 0.701 \\
\cline { 2 - 6 } & Third Year & 22 & 34.55 & 4.160 & 0.887 \\
\hline
\end{tabular}


Table 4: Significance of the Level of Study Habits based on Level of study

\begin{tabular}{|c|c|c|c|c|c|c|c|c|c|c|}
\hline & \multicolumn{2}{|c|}{$\begin{array}{l}\text { Levene's Test } \\
\text { for Equality } \\
\text { of Variances }\end{array}$} & \multicolumn{7}{|c|}{ t-test for Equality of Means } \\
\hline & & \multirow[t]{2}{*}{$\mathbf{F}$} & \multirow[t]{2}{*}{ Sig. } & \multirow[t]{2}{*}{$\mathbf{t}$} & \multirow[t]{2}{*}{ Df } & \multirow[t]{2}{*}{$\begin{array}{c}\text { Sig. } \\
(2-\text { tailed })\end{array}$} & \multirow[t]{2}{*}{$\begin{array}{c}\text { Mean } \\
\text { Difference }\end{array}$} & \multirow[t]{2}{*}{$\begin{array}{l}\text { Std. Error } \\
\text { Difference }\end{array}$} & \multicolumn{2}{|c|}{$\begin{array}{c}95 \% \text { Confidence } \\
\text { Interval of the } \\
\text { Difference }\end{array}$} \\
\hline & & & & & & & & & Lower & Upper \\
\hline $\begin{array}{c}\text { SH } \\
\text { combined }\end{array}$ & $\begin{array}{l}\text { Equal variances } \\
\text { assumed } \\
\text { Equal variances } \\
\text { not assumed }\end{array}$ & 0.259 & 0.613 & $\begin{array}{l}-1.762 \\
-1.773\end{array}$ & $\begin{array}{c}57 \\
45.169\end{array}$ & $\begin{array}{l}.083 \\
.083\end{array}$ & $\begin{array}{l}-2.005 \\
-2.005\end{array}$ & $\begin{array}{l}1.138 \\
1.131\end{array}$ & $\begin{array}{l}-4.284 \\
-4.282\end{array}$ & $\begin{array}{l}.274 \\
.272\end{array}$ \\
\hline
\end{tabular}

The t-test was calculated to determine whether there was any significant difference of the study habits of the students between levels of study. Table 3 indicates that the third years displayed better study habits than the first years since the third years had a mean score of 34.55 while the first years had a mean of 32.54. Furthermore, the mean score of the first year students suggest that on average they have poor study habits. Although this was illustrated in Table 3, the t-test shows that statistically there is no significant difference between the level of study habits based on level $(F=0.259, p=0.083)$.

It was expected that the third years would display better study habits than the first years. The first years have now entered a new educational institution where the working environment is completely different from what they have grown accustomed to. They have brought with them their own ways and ideas of how to study and have not yet developed or adjusted them while being in level one (Khurshid, et al., 2012). Third years on the other hand, have had time to mature within their study habits over the years and gain a better understanding on what may or may not work for them within a particular course (Khurshid, et al., 2012). Consequently, modifications can be done resulting in more effective study habits.

\subsection{Learning Styles}

Table 5 seeks to answer Research question 4(i) which stated: Is there any significant difference in the learning styles of the undergraduate Chemistry students based on level?

Table 5: Significance of Level on Learning Styles

\begin{tabular}{|l|l|l|l|l|l|l|l|l|}
\hline Variable & Category & N & Mean & $\begin{array}{l}\text { Std. } \\
\text { Deviation }\end{array}$ & Df & t & F & $\begin{array}{l}\text { Sig. } \\
\text { (2-tailed) }\end{array}$ \\
\hline Extrovert/ & First Year & 37 & 1.78 & 0.417 & 57 & 0.468 & 0.898 & 0.629 \\
Introvert & Third Year & 22 & 1.73 & 0.456 & & & & \\
\hline Sensate/ & First Year & 37 & 1.30 & 0.463 & 57 & -0.868 & 2.343 & 0.389 \\
Intuitive & Third Year & 22 & 1.41 & 0.503 & & & & \\
\hline Feeling/ & First Year & 37 & 1.76 & 0.435 & 57 & 0.247 & 0.237 & 0.806 \\
Thinking & Third Year & 22 & 1.73 & 0.456 & & & & \\
\hline Judging/ & First Year & 37 & 1.41 & 0.498 & 57 & 1.924 & 0.171 & 0.511 \\
Perceiving & Third Year & 22 & 1.32 & 0.447 & & & & \\
\hline
\end{tabular}

In scoring the learning style preferences, a value of 1 was used to represent the extrovert, sensate, feeling and judging categories while a value of 2 represented the introverts, intuitive, thinking and perceiving categories. Both the first year and third years showed high numbers of introverts since the mean scores were closer to 2. The t-test demonstrates that there was no statistical difference in the extrovert and introvert learning styles based on level of study $(F=0.898, p=0.629)$. In addition, there is an increase in the mean score of the intuitive learners from 1.30 in first years to 1.41 in third years. Thus, illustrating that as the level of study increases as the number of intuitive learners increase. However, while this was observed the t-test suggests that 
statistically there was no significant difference $(F=2.343, p=0.389)$ in the sensate/intuitive learning styles based on level of study. The mean scores obtained for the feeling and thinking learning styles indicate that there were more thinkers than feelers in both levels of study but the t-test indicates that statistically there is no significant difference in the feeling/thinking learning styles based on level $(F=0.237, p=0.806)$. As we move from first year to third there is a slight decrease in the number of perceivers. The first years had a mean score of 1.41 and this decreased slightly to 1.32 for the third years. Although this was observed, the t-test demonstrates that there was no statistical difference in the judging/perceiving learning styles based on level $(F=0.171, p=0.511)$. Even though all t-test results indicate that there is no statistical difference in learning styles based on level it is interesting to note that only the sensate/intuitive and the judging/perceiving dimensions showed any difference in the mean scores. Students may find themselves becoming more in tuned with their learning styles as they increase their level of study. The course material associated with Chemistry may require students to become more intuitive and judging. Such course material could involve abstract concepts along with structured and ordered instruction (Felder, et al., 2002; Larkin-Hein \& Budny, 2000). Students with extroversion, introversion, feeling or thinking learning preferences are more adaptable to particular learning situations and this may be a reason as to why no difference was seen in the year levels.

Perceivers like spontaneity and dislike having deadlines on assignments (Felder, et al., 2002). Unlike perceivers the judgers are more systematic and organized (Varughese, 2007). They also prefer well defined instruction (Felder, et al., 2002) and like when their work is completed (Larkin-Hein \& Budny, 2000). The judging learning style preference is associated with science students(Varughese, 2007). As the students are trained more in Chemistry they may become more judging than perceiving. Table 5 illustrates that the third years have more judgers (1.32) than the first years (1.41). This information suggests that as students increase in the level of study, their level of maturity in Chemistry also increases. They have completed enough years at the university to understand the concepts of Chemistry. Thus they are more capable of effectively adapting or changing their learning style to suit the settings that are being taught.

Table 6 answers part (iii) of the research question which states: Is there any significant difference in the learning styles of the undergraduate Chemistry students based on study habits?

Table 6: Significance between Study Habits based on Learning Styles

\begin{tabular}{|l|l|l|l|l|l|l|l|l|}
\hline Variable & Category & $\mathbf{N}$ & Mean & $\begin{array}{l}\text { Std. } \\
\text { Deviation }\end{array}$ & Df & t & F & Sig.(2-tailed) \\
\hline \multirow{5}{*}{ SH } & Extrovert & 14 & 1.29 & 0.469 & 23.084 & -1.087 & 6.747 & 0.288 \\
& Introvert & 45 & 1.44 & 0.503 & & & & \\
\cline { 2 - 9 } & Sensate & 39 & 1.33 & 0.478 & 57 & -1.612 & 1.902 & 0.113 \\
& Intuitive & 20 & 1.55 & 0.510 & & & & \\
\cline { 2 - 9 } & Feeling & 15 & 1.53 & 0.516 & 57 & 1.149 & 1.007 & 0.255 \\
& Thinking & 44 & 1.36 & 0.487 & & & & \\
\cline { 2 - 9 } & Judging & 37 & 1.35 & 0.484 & 57 & -1.117 & 2.061 & 0.269 \\
& Perceiving & 22 & 1.50 & 0.512 & & & & \\
\hline
\end{tabular}

The mean score of the introverts (1.44) indicates that they possess poorer study habits than the extroverts (1.29) as seen in Table 6. Even though this observation was made the results of the t-test indicate that there is no statistical difference in the study habits of the students based on the extrovert/introvert dimension ( $F=6.747$, $p=0.228$ ). It was expected that the introverts would have better study habits seeing as they usually prefer to be alone and reflect on work (Varughese, 2007). Extroverts prefer more group activities and person to person communication (Varughese, 2007). However daydreaming in class and becoming distracted or tired after studying for long periods of time may have contributed to the results. Lectures may at times have included group participation which suits the extroverts and they may have paid more attention while the introverted students could have been uncomfortable in the environment and may find themselves daydreaming.

In regards to the sensate/intuitive dimension a mean score of 1.33 was obtained for the sensate students indicating that they possessed better study habits than the intuitive students (1.55). Nevertheless, the t-test results showed that there was no statistical difference in study habits based on the sensate/intuitive dimension $(F=1.902, p=0.113)$. Sensors prefer repetition and small details more so than the intuitive students and could be 
a possibly explanation for the observation (Larkin-Hein \& Budny, 2000; Richards, et al., 1999). Attention to small details may give the sensors and advantage when reviewing course material since they are able to pick out the important information associated with the material. They may not easily get tired after studying for long periods of time unlike the intuitive students who dislike repetition.

Furthermore, based on the mean scores the feelers (1.53) displayed poorer study habits than the thinkers (1.36). Further analysis of the results using a t-test showed that there was no significant statistical difference in study habits based on the feeling/thinking dimension ( $F=1.007, p=0.255)$. This was not surprising given the fact that thinkers would prefer more analytical and logical thinking (Varughese, 2007) making it easier for them to study the course material. In addition, feelers who are generally more in tuned to their feelings (Varughese, 2007) may find themselves worrying about doing well on the test and this may interfere with their study time.

The perceivers (1.50) displayed poorer study habits than the judgers (1.35). Judgers tend to be very well organized (Larkin-Hein \& Budny, 2000) and so it is possible that they planned their time wisely to include note review and study sessions. On the other hand perceivers are generally not as organized as judgers and tend to procrastinate when it comes to studying or completing assignments (Larkin-Hein \& Budny, 2000; Varughese, 2007). They probably end up cramming for tests at times and this could contribute to their poor study habits. The t-test results in Table 6 suggest that statistically there was no significant difference in study habits based on the judging/perceiving dimension ( $F=2.061, p=0.269)$.

\subsection{Academic Achievement (AA)}

Academic achievement was assessed by a test on Group Theory. Group Theory in Chemistry involves concepts from aspects of mathematics and science (Harle \& Towns, 2010). It involves the analysis of symmetry and operations of molecular models (Harle \& Towns, 2010; Meyer \& Sargent, 2007). Table 7 illustrates the significance of academic achievement based on study habits and learning styles and seeks to answer research question $5(\mathrm{i})$.

Table 7: Significance of Academic Achievement Based on Study Habits and Learning Styles

\begin{tabular}{|c|c|c|c|c|c|c|c|c|}
\hline Variable & Category & $\mathbf{N}$ & Mean & $\begin{array}{l}\text { Std. } \\
\text { Deviation }\end{array}$ & Df & $\mathbf{t}$ & $\mathbf{F}$ & $\begin{array}{l}\text { Sig. } \\
\text { (2-tailed) }\end{array}$ \\
\hline \multirow{5}{*}{$A A$} & $\begin{array}{l}\text { Good Study Habits } \\
\text { Poor Study Habits }\end{array}$ & $\begin{array}{l}35 \\
24\end{array}$ & $\begin{array}{l}53.26 \\
53.67\end{array}$ & $\begin{array}{l}19.3837 \\
22.7322\end{array}$ & 57 & -0.074 & 0.416 & 0.941 \\
\hline & $\begin{array}{l}\text { Extrovert } \\
\text { Introvert }\end{array}$ & $\begin{array}{l}14 \\
45 \\
\end{array}$ & $\begin{array}{l}61.43 \\
50.93\end{array}$ & $\begin{array}{l}19.2702 \\
20.2928 \\
\end{array}$ & 57 & 1.690 & 0.233 & 0.097 \\
\hline & $\begin{array}{l}\text { Sensate } \\
\text { Intuitive }\end{array}$ & $\begin{array}{l}39 \\
20\end{array}$ & $\begin{array}{l}55.46 \\
40.45\end{array}$ & $\begin{array}{l}20.8577 \\
20.0996\end{array}$ & 57 & 1.061 & 0.010 & 0.293 \\
\hline & $\begin{array}{l}\text { Feeling } \\
\text { Thinking }\end{array}$ & $\begin{array}{l}15 \\
44 \\
\end{array}$ & $\begin{array}{l}52.27 \\
53.82\end{array}$ & $\begin{array}{l}22.7830 \\
20.0978\end{array}$ & 57 & -0.250 & 0.391 & 0.804 \\
\hline & $\begin{array}{l}\text { Judging } \\
\text { Perceiving }\end{array}$ & $\begin{array}{l}37 \\
22\end{array}$ & $\begin{array}{l}51.16 \\
57.23\end{array}$ & $\begin{array}{l}21.3444 \\
19.2154\end{array}$ & 57 & -1.094 & 0.581 & 0.278 \\
\hline
\end{tabular}

Looking at the mean values (Table 7) it was interesting to see that those students with poor study habits achieved relatively the same grades as those students with good study habits for the group theory test that was taken. The results for the t-test performed further exemplifies that statistically there was no significant difference in academic achievement based on study habits $(F=0.416, p=0.941)$. This is very surprising as one would think that those with better study habits would have scored higher on the test. While a student may possess on average good study habits it is possible that he/she is lacking in a particular area. For example some these students may daydream or fall asleep during lectures and miss vital information pertaining to the course and consequently the test. They may also get tired or distracted easily when studying for long periods of time and would being unprepared for the test. Furthermore, the study habits of the students whether good or poor may match their learning style allowing the student to efficiently process and retain the reading material as well as 
other additional information from various sources Thus, students with poor study habits are able to answer just as well as those with good study habits.

Subsequent to this finding the relationship between learning styles and academic achievement was investigated. The t-test results seen in Table 7 indicates that there is no statistical difference in academic achievement based on the extrovert and introvert learning styles $(F=0.233, p=0.097)$. However, within the same table it was found that the extroverts outperformed the introverts obtaining a mean of 61.43 compared to 50.93 . These results are not consistent with the data reported in previous studies (Kazu, 2009; Schmid, et al., 2009; Yeung, et al., 2005)which showed that the introverts outperformed the extroverts. During Group Theory tutorials sessions there were group interaction among the students and the incorporation molecular models. The students had the opportunity to work in groups and building stick-and-ball models of the molecules being discussed. These same models were borrowed by some of the students while other made their own using playdough, sticks or pins. These models were then utilized by the students during their study groups and this type of environment is more suited towards the extrovert. Consequently, the extroverts may absorb and retain more information resulting in the higher academic performance by the extroverts. It must be noted however, the extroverts did indeed possess better study habits than the introverts (Table 6).

On the other hand, the sensors performed slightly better than the intuitive students given that the mean grade attained by the sensors was 55.46 and that of the intuitive students was 40.45 . The t-test suggests that statistically there is no significant difference in academic achievement based on the sensate and intuitive learning styles $(F=0.10, p=0.293)$. It was unexpected that the sensors would perform better than the intuitive students since group theory usually includes more abstract concepts but since the sensors displayed better study habits (Table 6) it could have led to the difference in grades. A study performed among Chemistry students (Yeung, et al., 2005) has shown that the sensate/dimension did not affect academic achievement. Additionally, intuitive students tend to see the "big picture" with little regard for smaller details and this may have been a disadvantage to them in group theory. They unlike the sensors who prefer small details may not have been able to work through the questions step by step to fully answer the questions having mentally visualized the molecule 3 dimensionally.

Moreover, it was expected for the thinkers to attain better grades than the feelers since the thinking learning style has been more associated with science (Varughese, 2007) and group theory involves more logical thinking. From the results they did not do exceptionally well over the feelers. In fact the thinkers received an average grade of 53.82 and the feelers 52.27 for the group theory test. Table 7 shows that statistically there is no significant difference in academic achievement based on both learning style preferences $(F=0.391, p=0.804)$. The higher performance seen with the thinkers correlates to the other findings (Yeung, et al., 2005) where the researchers found the thinkers performed better than the feelers.

For the judging and perceiving learning styles the results of the t-test suggest that there is no statistical difference in academic achievement $(F=0.581, p=0.278)$. However, it is illustrated in Table 7 that the perceivers having a mean grade of 57.23 outperformed the judgers with a mean grade of 51.16. Yeung, et al., (2005) reported that the judging/perceiving dimension does not affect academic achievement. The judging learning style is associated with science not perceiving. In addition, the perceivers possessed poorer study habits than the judgers and subsequently one can say that study habits did not affect their academic achievement. Matched study habits and learning styles could be a possible reason for the results obtained. The students could effectively process the information in the course material in preparation for the test and thus score higher than the judgers.

\subsection{Combined Effect and Relative Contribution of Learning Styles and Study Habits on Academic Achievement}

Tables 8 and 9 seek to answer Research questions 6 and 7 which deal with the combined effect and contribution of learning styles and study habits on academic achievement. 
Table 8: Combined effect of Learning Styles and Study Habits on Academic Achievement

\begin{tabular}{|c|c|c|c|c|c|}
\hline \multicolumn{6}{|c|}{$\begin{array}{l}R=0.305 \\
R^{2}=0.093 \\
\text { Adjusted } R^{2}=0.007 \\
\text { Std. Error of the Estimate }=20.5444\end{array}$} \\
\hline \multicolumn{6}{|l|}{ ANOVA } \\
\hline Model & $\begin{array}{l}\text { Sum of } \\
\text { Squares }\end{array}$ & Df & Mean Square & $\mathbf{F}$ & Sig. \\
\hline Regression & 2292.605 & 5 & 458.521 & 1.086 & 0.379 \\
\hline \multirow[t]{2}{*}{ Residual } & 22369.802 & 53 & 422.072 & & \\
\hline & 24662.407 & 58 & & & \\
\hline
\end{tabular}

Table 9: Relative Contribution of Each Factor on Academic Achievement

\begin{tabular}{|l|l|l|l|l|l|}
\hline & \multicolumn{2}{|l|}{ Unstandardized Coefficients } & $\begin{array}{l}\text { Standardized } \\
\text { Coefficients }\end{array}$ & & \\
\hline Model & B & Std. Error & Beta & t & Sig. \\
\hline Constant & 82.962 & 31.948 & ---- & -0.228 & 0.012 \\
\hline EI & -10.966 & 6.562 & -0.228 & -.0183 & 0.101 \\
\hline SN & -7.889 & 5.766 & -0.183 & 0.009 & 0.177 \\
\hline FT & 0.400 & 6.555 & 0.009 & 0.120 & 0.952 \\
\hline JP & 5.073 & 6.051 & 0.120 & -0.046 & 0.406 \\
\hline SH & -0.220 & 0.671 & -0.046 & -0.228 & 0.745 \\
\hline
\end{tabular}

A combination of the E/I, S/N, F/T and J/P dimensions along with study habits accounted for 9,3\% of the variance $\left(R^{2}=0.093, p=0.379\right)$. While Table 8 suggests that statistically there is no significant difference in contribution $(F=1.086 p=0.379)$, Table 9 suggests that that the highest contribution to academic achievement was the extrovert/introvert category of learning styles $(\beta=0.228)$, sensate/intuitive $(\beta=0.183)$, judging/perceiving $(\beta=0.120)$, study habits $(\beta=0.046)$ and finally feeling/thinking $(\beta=0.009)$.

\section{Conclusion}

Learning style and study habits are important in one's academic pursuit. This study revealed that among the chemistry students at the University of the West Indies the prevailing learning style preferences were introvert, sensate, thinking and judging and that they had good study habits. However, there was no significant difference in the academic achievement of the students in chemical group theory based on learning style preferences and or learning style preferences.

\section{References}

Abidin, M. J. Z., Rezaee, A. A., Abdullah, H. N., \& Singh, K. K. B. (2011). Learning Styles and Overall Academic Achievement in a Specific Educational System. International Journal of Humanities and Social Science. Retrieved from https://www.academypublisher.com/ academz3/ojs/index.php/tpls/article/viewFile/011114881496/3867

Aluja-Fabregat, A., \& Blanch, A. (2004). Socialized Personality, Scholastic Aptitudes, Study Habits, and Academic Achievement: Exploring the Link. European Journal of Psychological Assessment, 20(3), 157. Retrieved from http://web.udl.es/usuaris/e7806312/grup/aaluja-archi/arti_aluja/pu_47.pdf. doi:10.1027//1015-5759.20

Bailey, P. D., \& Garratt, J. (2002). Chemical education: theory and practice, University Chemistry Education (Vol. 6, pp. 3957). Available from http://www.rsc.org/pdf/uchemed/papers/2002/p8_bailey.pdf

Bashir, I., \& Mattoo, N. H. (2012). A Study on Study Habits and Academic Performance among Adolescents (14-19) years. International Journal of Social Science Tomorrow, 1-5. Retrieved from http://ijsst.com/issue/610.pdf 
Blumner, H. N., \& Richards, H. C. (1997). Study habits and academic achievement of engineering students. JOURNAL OF ENGINEERING EDUCATION-WASHINGTON-, 86, 125-132. Retrieved from http://www.jee.org/1997/april/518.pdf

Credé, M., \& Kuncel, N. R. (2008). Study habits, skills, and attitudes: The third pillar supporting collegiate academic performance. Perspectives on Psychological Science, 3(6), 425-453. Retrieved from http://128.228.178.102/export_test5/main/about/administration/offices/aa/acr/protected/June10Article.pdf

Estes, T. H., \& Richards, H. C. (1985). Habits of study and test performance. Journal of Literacy Research, 17(1), 1-13. Retrieved from http://jlr.sagepub.com/content/17/1/1.full.pdf

Felder, R. M., Felder, G., \& Dietz, E. (2002). The effects of personality type on engineering student performance and attitudes. JOURNAL OF ENGINEERING EDUCATION-WASHINGTON-, 91(1), 3-18. Retrieved from http://www4.ncsu.edu/unity/lockers/users/f/felder/public/Papers/longmbti.pdf

Felder, R. M., \& Silverman, L. K. (1988). Learning and teaching styles in engineering education. Engineering education, 78(7), 674-681. Retrieved from http://www4.ncsu.edu/unity/lockers/users/f/felder/public/Papers/LS-1988.pdf

Gettinger, M., \& Seibert, J. K. (2002). Contributions of study skills to academic competence. School Psychology Review, 31(3), 350-365. Retrieved from http://www.wce.wwu.edu/Depts/SPED/Forms/Kens\%20Readings/ Instruction/Instruct\%20Contributions\%20of\%20study\%20skills\%20Gettinger\%202002.pdf

Hamidah, J. S., Sarina, M. N., \& Jusoff, K. (2009). The Social Interaction Learning Styles of Science and Social Science Students. Asian Social Science, 5(7), P58. Retrieved from http://scholar.google.com/scholar?q=The+ Social+Interaction+Learning +Styles + of +Science + and +Social +Science+Students\&btnG = \&hl =en\&as_sdt $=0 \% 2 C 5$

Harle, M., \& Towns, M. (2010). A Review of Spatial Ability Literature, Its Connection to Chemistry, and Implications for Instruction. Journal of Chemical Education, 88(3), 351-360. Retrieved from http://www.chem.purdue.edu/towns/Towns\%20Publications/Harle\%20Towns\%202010.pdf

Hauptman, H., \& Cohen, A. (2011). The synergetic effect of learning styles on the interaction between virtual environments and the enhancement of spatial thinking. Computers \&amp; Education, 57(3), 2106-2117. Retrieved from http://www.sciencedirect.com/science/article/pii/S036013151100114X. doi:10.1016/j.compedu.2011.05.008

Hoeffner, K. A. (2010). The effects of learning-styles information on the achievement of community college developmental math students. University of South Florida.

Huang, R., \& Busby, G. (2007). Activist, pragmatist, reflector or theorist? In search of postgraduate learning styles in tourism and hospitality education. Journal of Hospitality, Leisure, Sport, and Tourism Education, 6(2), 92-99. Retrieved from http://www-new2.heacademy.ac.uk/assets/hlst/documents/johlste/vol6n02/154_huang_ vol6no2.pdf

International Office: International Students: FAQs. (2012). Retrieved 27th November,2012, from http://www.cavehill.uwi.edu/international/intl/faqs.asp

Jones, C., Reichard, C., \& Mokhtari, K. (2003). ARE STUDENTS'LEARNING STYLES DISCIPLINE SPECIFIC? Community College Journal of Research \&Practice, 27(5), 363-375. Retrieved from http://metawiki-onlinelearningbrockport.pbworks.com/f/jonesetal.pdf

Kazu, I. (2009). The effect of learning styles on education and the teaching process. Journal of Social Sciences, 5(2), 8594. Retrieved from http://perweb.firat.edu.tr/personel/yayinlar/fua_35/35_59283.pdf

Khurshid, D. F., Tanveer, A., \& Qasmi, F. N. (2012). Relationship between Study Habits and Academic Achievement among Hostel Living and Day Scholars' University Students. British Journal of Humanities and Social Sciences, $3(2)$, 34-42. Retrieved from http://www.ajournal.co.uk/HSpdfs/HSvolume3\%282\%29/HSVol,3\%20\%282 \%29\%20Article\%204.pdf

Kolb, D. A. (1981). Learning styles and disciplinary differences. The modern American college, 232-255. Retrieved from http://learningfromexperience.com/media/2010/08/Learning-styles-and-disciplinary-difference.pdf

Kolb, D. A. (1984). Experiential learning: Experience as the source of learning and development: Prentice Hall.

Kolb, D. A., Boyatzis, R. E., \& Mainemelis, C. (2001). Experiential learning theory: Previous research and new directions. Perspectives on thinking, learning, and cognitive styles, 1, 227-247. Retrieved from http://www.d.umn.edu $\angle \sim$ kgilbert/educ5165-731/Readings/experiential-learning-theory.pdf

Larkin-Hein, T., \& Budny, D. D. (2000). Why Bother Learning about Learning Styles and Psychological Types? Paper presented at the Proceedings of the 2000 ASEE Annual Conference and Exposition, St. Louis, MO.

Leacock, C., Warrican, S., Rose G. (2009). Research methods for inexperienced researchers. Kingston Jamaica: Ian Randle Publishers.

Linn, M. C., \& Hyde, J. S. (1989). Gender, mathematics, and science. Educational Researcher, 18(8), 17-27

Meyer, D. E., \& Sargent, A. L. (2007). An interactive computer program to help students learn molecular symmetry elements and operations. Journal of Chemical Education, 84(9), 1551. Retrieved from http://www.ecu.edu/cscas/chem/upload/Documentation_web.pdf 
Montgomery, S. M., \& Groat, L. N. (1998). Student learning styles and their implications for teaching. CRLT Occasional Papers, 10, 1-8. Retrieved from https://www.eecs.umich.edu/cse/cs_connections/cs4hs_presentations_09/ Student_Learning_Styles.pdf

Nuthana, P., \& Yenagi, G. V. (2009). Influence of study habits, self-concept on academic achievement of boys and girls. Karnataka J. Agric. Sci, 22(5), 1135-1138. Retrieved from http://pub.uasd.edu/ojs/index.php/kjas/article/ viewFile/1510/1444

O'Brien, T. P., Bernold, L. E., \& Akroyd, D. (1998). Myers-Briggs type indicator and academic achievement in engineering education. International Journal of Engineering Education, 14, 311-315. Retrieved from http://www.ijee.ie/articles/Vol14-5/ijee1039.pdf

Rana, S. A., \& Kausar, R. (2011). Comparison of Study Habits and Academic Performance of Pakistani British and White British Students. Pakistan Journal of Social and Clinical Psychology, 9, 21-26. Retrieved from http://www.gcu.edu.pk/FullTextJour/PJSCS/2011/4.pdf

Richards, L. G., Richards, H. C., \& Sheridan, D. C. (1999). Predicting success in a first year engineering course: the role of study habits. Paper presented at the FRONTIERS IN EDUCATION CONFERENCE.

Santos, J. R. A. (1999). Cronbach's alpha: A tool for assessing the reliability of scales. Journal of extension, 37(2), 1-5. Retrieved from http://www.joe.org/joe/1999april/tt3.php

Schmid, S., Yeung, A., \& Read, J. (2009). Students' Learning Styles and Academic Performance. In M. Gupta-Bhowon, S. Jhaumeer-Laulloo, H. L. K. Wah \& P. Ramasami (Eds.), Chemistry Education in the ICT Age (pp. 249-262): Springer Netherlands.

Shabani, M. B. (2012). Different Learning Style Preferences of Male and Female Iranian Non-academic EFL Learners. English Language Teaching, 5(9), p127. Retrieved from http://journal.ccsenet.org/index.php/elt/article/view/19344

Shindler, J., \& Yang, H. (2004). Paragon Educational Consulting Student Learning Style Inventory version 48a Available from http://www.calstatela.edu/faculty/jshindl/plsi/plsi48a.htm

Smith, P. J., \& Dalton, J. (2005). Getting to grips with learning styles Available from http://johnwatsonsite.com/ShareEng/SIC/Getting_to_grips_with_learnng_styles.pdf

Tasker, R., Miller, J., Kemmett, C., \& Bedgood Jr, D. R. (2003). Analysis of student engagement with online chemistry modules using tracking data. Paper presented at the Interact, Integrate, Impact: Proceedings of the 20th Annual Conference of the Australasian Society for Computers in Learning in Tertiary Education. .

Tavakol, M., \& Dennick, R. (2011). Making sense of Cronbach's alpha. International Journal of Medical Education, 2, 5355. Retrieved from http://www.ijme.net/archive/2/cronbachs-alpha.pdf

Tucker, R. (2007). Southern drift: The learning styles of first-and third-year students of the built environment. Architectural science review, 50(3), 246-255. Retrieved from http://sydney.edu.au/architecture/documents/ publications/ASR/Southern\%20Drift.pdf

Varughese, V. K. (2007). Students' Approaches to Learning: A Case Study of Learning Biology in Foundation Studies at the Royal Melbourne Institute of Technology University. RMIT University.

Wrenn, C. G., Larsen, R. P., \& Effectively, S. (1974). Studying effectively Available from http://books.google.com/books?hl=en\&lr=\&id=3YmaAAAAIAAJ\&oi=fnd\&pg=PA1\&dq =C. + G + Wrenn, $+1974 \&$ ot $\mathrm{s}=$ YRUUXqFmDO\&sig=MrOom5Tk1MuzY6-Yv6n7jGo27Vg\#v=onepage\&q\&f=false

Yeung, A., Read, J., \& Schmid, S. (2005). Students' learning styles and academic performance in first year chemistry. Sydney, Australia: The University of Sydney. Retrieved from http://science.uniserve.edu.au/pubs/procs/ wshop10/2005Yeung.pdf

Yeung, A., Read, J. R., \& Schmid, S. (2006). Are learning styles important when teaching chemistry? Chemistry in Australia, 73(11), 10-13 